УДК 159.923-053.5:[37.015.3:78]

DOI https://doi.org/10.26661/2310-4368/2020-2-20

\title{
ПРОГРАМА РОЗВИТКУ ІНДИВІДУАЛЬНОСТІ МОЛОДШОГО ШКОЛЯРА У ПРОЦЕСІ МУЗИЧНОЇ ДІЯЛЬНОСТІ: ЗМІСТОВІ ТА ПРОЦЕСУАЛЬНІ АСПЕКТИ
}

\author{
Олефір В. П. \\ старший викладач кафедри спечіальної психології та медицини \\ факультету спеціальної та інклюзивної освіти \\ Національний педагогічний університет імені М. П. Драгоманова \\ вул. Пирогова, 9, Киї, Украӥна \\ orsid.org/0000-0003-1016-7595 \\ valentyna.olefir9@gmail.com
}

\begin{abstract}
Ключові слова:
індивідуальність, молодший школяр, музична діяльність, модель становлення індивідуальності, психологічні умови, навчально-розвивальні заняття.
\end{abstract}

У статті акцентується увага на важливості розвитку індивідуальності молодшого школяра в музичній діяльності. Представлена теоретична модель становлення індивідуальності молодшого школяра, що визначає структуру програми розвитку індивідуальності та послідовність іiі впровадження в просторінавчальногопроцесузагальноосвітньоїшколи. Встановлене основне завдання програми - актуалізація таких психологічних умов становлення індивідуальності молодшого школяра у процесі музичної діяльності, як оптимальний рівень тривожності, адекватна самооцінка, позитивна мотивація навчання, ефективне цілепокладання, розвинений самоконтроль та саморегуляція поведінки, креативність, досвід міжособистісної взаємодії. Визначаються основні принципи, дотримання яких важливе під час роботи iз молодшими школярами у заданому напрямі: активної участі, творчої активності та співробітництва, принцип «тут i тепер», діалогічності, рівноправного спілкування, індивідуального підходу, зворотного зв'язку, толерантної та коректної педагогічної оцінки. Розкриваються особливості програми розвитку індивідуальності молодшого школяра в музичній діяльності, що являє собою створений авторський цикл навчальнорозвивальних занять «Розвиток індивідуальності молодшого школяра на урокахмузики»таспрямовананарозвитокнавичоксамопізнання, формування адекватного уявлення, позитивного ставлення до себе, розвиток здатності до самостійної постановки цілей, умінь цілереалізації; оволодіння прийомами саморегуляції, формування довільної уваги, подолання імпульсивності, розвиток вольових якостей; формування позитивного ставлення до навчання; розвиток пізнавального інтересу, комунікативних навичок, доброзичливості, чуйності, толерантності. Описуються заняття програми, що являють собою комплекс вправ/процедур як авторської модифікації, так і запозичених, які представляють активні методи соціально-психологічного навчання (групова дискусія, рольова гра, вправи на самопізнання і самооцінювання, вправи для розминки), що виконуються в рамках основних видів музичної діяльності слухання музики, співу, інтонування, гри на музичних інструментах, імпровізації, засвоєння музичних знань. 


\title{
THE PROGRAM OF DEVELOPMENT OF JUNIOR SCHOOLCHILD INDIVIDUALITY DURING THE MUSICAL ACTIVITY: SUBSTANTIVE AND PROCEDURAL ASPECTS
}

\author{
Olefir V. P. \\ Assistant Professor at the Department of Special Psychology and Medicine \\ of the Faculty of Special and Inclusive Education \\ National Pedagogical Dragomanov University \\ Pyrohova str., 9, Kyiv, Ukraine \\ orsid.org/0000-0003-1016-7595 \\ valentyna.olefir9@gmail.com
}

Key words: individuality, junior schoolchild, musical activity, model of individuality becoming, psychological conditions, educational and developmental lessons.
The article emphasizes the importance of the development of junior schoolchild's individuality during musical activity. The author has presented the theoretical model of becoming individuality of the junior schoolchild that determined the structure of individuality development program and consistency of its introduction in the context of teaching and learning activities of a general education school. It has been set the key program task - to maintain such psychological conditions for personal becoming of the junior schoolchild during musical activity as an optimal level of anxiety, reasonable self-esteem, positive motivation for education, effective goal setting, developed self-control and self-regulation of behavior, creativity, experience of the interpersonal interaction. The research has identified the basic principles the observance of which is essential during the work with junior schoolchildren in the specified field: an active participation, creative activity and co-cooperation, the "the here and now" principle, the dialogic principle, equal communication, personalized approach, feedback, tolerance and reasonable pedagogical assessment. It has been specified features of the program for the development of junior schoolchild's personality during musical activity that is the author's cycle of educational and developmental practices "Development of personality of a junior schoolchild at music lessons". The program is designed to build self-awareness skills, form adequate perception, positive attitude to oneself, develop a capacity of independent goal-setting, skills for goal achievement, master self-adjustment techniques, form passive attention, overcome impulsion, advance endurance and stamina, form positive attitude to education, cultivate cognitive interest, social skills, agreeableness, empathy, tolerance. It has been described the program lessons which consist of a complex of exercises/procedures both of the author's modification and borrowed one, which are active methods of the socio-psychological education (a group discussion, role game, exercises for selfawareness and self-esteem, warm-up activities) and executed under the framework of basic kinds of musical activity - listening to music, singing, intoning, playing musical instruments, improvisation, acquisition of musical knowledge.
Постановка проблеми. Проблема розвитку індивідуальності молодшого школяра у процесі музичної діяльності є актуальною для сучасної психолого-педагогічної науки, оскільки має соціальну значущість та не досить досліджена у науковій літературі. Прискорення темпів розвитку різних сфер суспільства, інформатизації, поширення масової культури, збільшення відчуження, нівелювання особистості визначають важливість проблеми розвитку та збереження індивідуальності. Одним із вікових періодів, особливості якого створюють сприятливе підгрунтя для становлення індивідуальності, є молодший шкільний вік.

Загалом проблема індивідуальності стала предметом вивчення широкого кола як зарубіжних, так і вітчизняних науковців. На думку В.У. Кузьменко, індивідуальність виступає унікальною динамічною системою, структурна основа якої утворюється шляхом поєднання комплексу відмінностей індивідного (темперамент, стан здоров'я, здібності та інтереси) та особистісного (самосвідомість, соціально-етичний, емоційно-вольовий, потребо- 
во-мотиваційний, інтелектуальний розвиток) конструктів [1]. Ми розглядаємо дане автором визначення як таке, що найбільш повно інтегрує у собі підходи до розуміння вищезазначеного поняття.

Проблема індивідуальності молодшого школяра стала спеціальним предметом теоретичних та емпіричних досліджень досить обмеженого кола науковців (Л.Л. Баландіна [2], О.С. Войтов [3], О.С. Гребенюк [4], Т.Б. Гребенюк [4], С.С. Давидова [5], Т.М. Хрустальова [6], С.Н. Шибаєва [7] та ін.), в яких встановлюються індивідуальні особливості дітей залежно від статі, характеристик сім'ї, педагогічної обдарованості, рівнів учбової мотивації, особистісної безпорадності тощо.

У наукових працях дослідників засвідчується, що залучення молодшого школяра до музичної діяльності позитивно позначається на таких феноменологічних утвореннях, які водночас характеризують його індивідуальність, як творча активність (Чж. Гуань [8]), креативність (А.В. Нєнахова [9], О.О. Травіна [10]), духовно-моральна культура (Л.П. Яненко [11]), моральні уявлення (Т.Б. Сандабкіна [12]), емоційна чуйність (О.В. Гордова [13]), універсальні учбові дії (Л.Л. Алєксєєва [14]), самопізнання (А.В. Криніцина [15]), досвід міжособистісної взаємодії (С.О. Мільтонян [16]), навички мисленнєвої діяльності (К.А. Міхєєва [17], Л.В. Яркіна [17]), оптимальний рівень тривожності, позитивна мотивація навчання (М.Б. Корольова [18]). Водночас ми не знайшли спеціальних цілісних наукових досліджень, присвячених проблемі розвитку індивідуальності молодшого школяра у процесі музичної діяльності, що спонукало до проведення нами констатувального експерименту, метою якого окреслилось встановлення психологічних особливостей прояву індивідуальності у молодшому шкільному віці та експериментальне виявлення психологічних умов становлення індивідуальності молодшого школяра. Отримані результати проведеного дослідження привели нас до висновків про те, що: 1) зафіксовані рівні вияву індивідуальності у молодших школярів не можуть бути задовільними, оскільки високий рівень виявляє незначна частина учнів молодшої школи, а більшість має середній та низький рівень розвитку індивідуальності; 2) визначальними психологічними умовами становлення індивідуальності молодшого школяра виступають: оптимальний рівень тривожності, адекватна самооцінка, позитивна мотивація навчання, ефективне цілепокладання, розвинений самоконтроль та саморегуляція поведінки, креативність, досвід міжособистісної взаємодії. Припущення про ефективність актуалізації таких умов 3 метою розвитку індивідуальності молодшого школяра в процесі музичної діяльності було покладено в основу розробки відповідної програми формувального експерименту.
Мета статті полягає у розкритті змістових та процесуальних аспектів програми формування індивідуальності молодшого школяра у процесі музичної діяльності.

Виклад основного матеріалу дослідження. Проведений ними констатувальний експеримент дозволив встановити особливості вияву індивідуальності молодших школярів, іiї зв'язок із тривожністю, самооцінкою, мотивацією навчання, цілепокладанням, самоконтролем та саморегуляцією поведінки, креативністю, досвідом міжособистісної взаємодії, що дозволило побудувати експериментальну програму з розвитку індивідуальності молодшого школяра в музичній діяльності.

Основною гіпотезою формувального експерименту стала ідея про те, що забезпечення актуалізації психологічних умов за допомогою спеціального психолого-педагогічного супроводу в музичній діяльності сприятиме розвитку індивідуальності молодшого школяра.

Таким чином, зосередження зусиль відбувалося в аспекті актуалізації психологічних умов становлення індивідуальності молодшого школяра у процесі музичної діяльності: оптимального рівня тривожності, адекватної самооцінки, позитивної мотивації навчання, ефективного цілепокладання, розвиненого самоконтролю та саморегуляції поведінки, креативності, досвіду міжособистісної взаємодії. Тому в програму були включені завдання на оптимізацію рівня тривожності, корекцію самооцінки, стимулювання позитивного ставлення до себе; розвитку цілепокладання, самоконтролю та саморегуляції поведінки, мотивації навчання, креативності, формування досвіду міжособистісної взаємодії.

Розроблена теоретична модель становлення індивідуальності молодшого школяра визначила структуру програми розвитку індивідуальності та послідовність її впровадження (рис. 1).

Програма розвитку індивідуальності молодшого школяра в музичній діяльності, що базується на розробленій моделі, являла собою розроблений авторський цикл навчально-розвивальних занять «Розвиток індивідуальності молодмого школяра на уроках музики», що проводились раз на тиждень у кількості однієї години (один урок тривалістю 45 хвилин) впродовж навчального року.

Під час проведення навчально-розвивальних занять важливим було дотримання таких принципів, як: принцип активної участі у виконанні завдань, що передбачає таке: якщо $є$ бажання щось сказати та обговорити, то це потрібно зробити, навіть якщо ніяково та страшно, водночас у кожного учня $\epsilon$ право промовчати, якщо це відповідає його внутрішньому стану; принцип творчої активності та співробітництва; принцип «тут і тепер»; принцип діалогічності, що передбачає 


\section{Становлення індивідуальності дітей молодшого} шкільного віку в процесі музичної діяльності

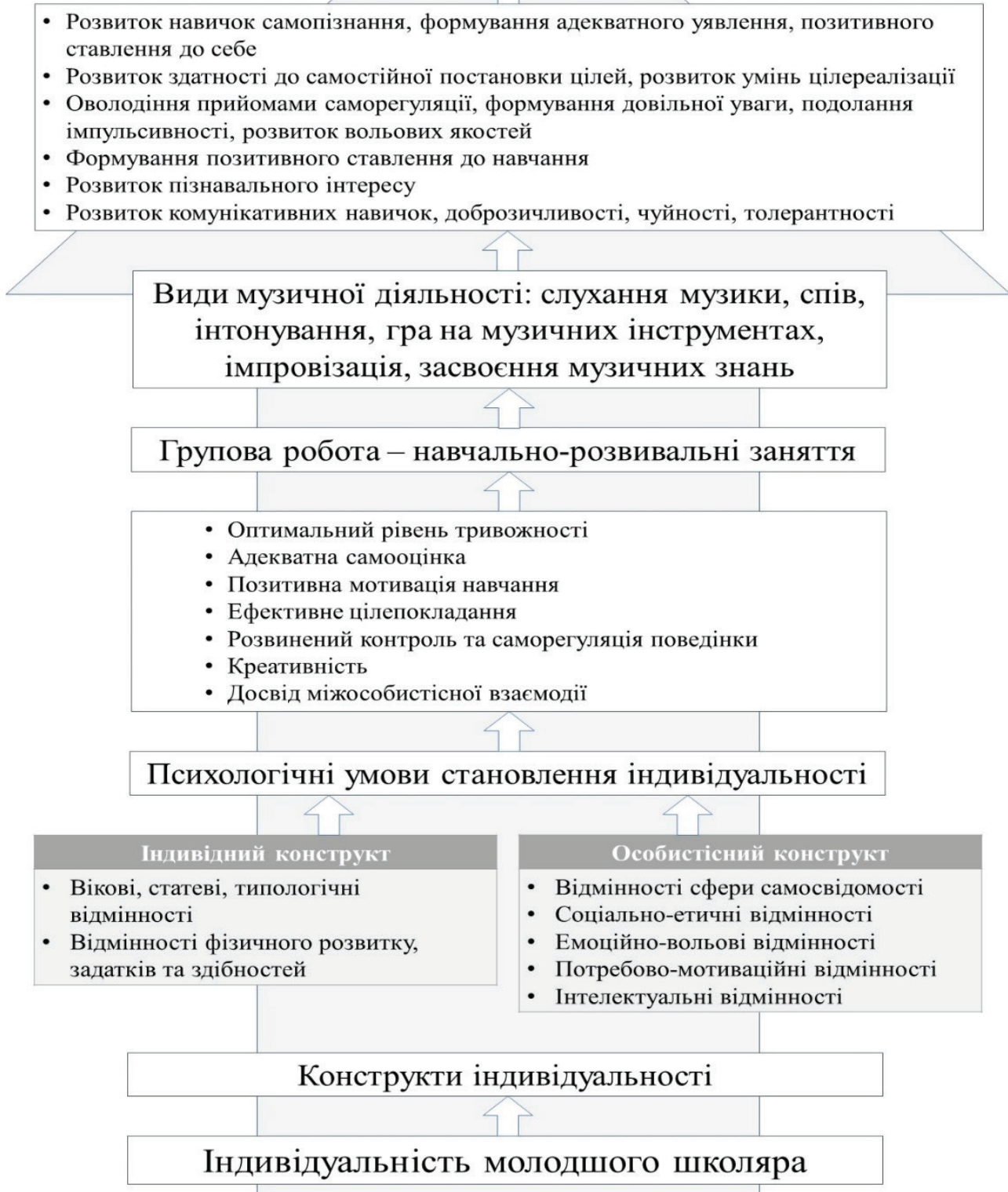

Рис. 1. Модель становлення індивідуальності молодшого школяра в процесі музичної діяльності

налагодження стосунків між учасниками педагогічного процесу. Рівноправне спілкування молодшого школяра 3 дорослим сприяє зміцненню його індивідуальності. У процесі проведення розвивальних занять акцентувалась увага на праві кожного учасника говорити та обов'язку слухати; принцип індивідуального підходу, що передбачає врахування особливостей вияву індивідуальності, рівня особистісних можливостей, міри відкритості у спілкуванні, характерологічних та темпераментних особливостей школяра; принцип зворот- ного зв'язку; принцип толерантної та коректної педагогічної оцінки [19, с. 146-147].

Кожне заняття являло собою комплекс вправ/процедур як авторської модифікації, так і запозичених, які представляють активні методи соціально-психологічного навчання (групова дискусія, рольова гра, вправи на самопізнання і самооцінювання, вправи для розминки), що виконувались у рамках основних видів музичної діяльності - слухання музики, співу, інтонування, гри на музичних інструментах, імпровізації, засвоєння музичних знань. 
Як зазначалося вище, завданнями програми розвитку індивідуальності молодшого школяра в музичній діяльності стали: оптимізація рівня тривожності, корекція самооцінки, стимулювання позитивного ставлення до себе; розвиток мотивації навчання, цілепокладання, самоконтролю та саморегуляції поведінки, креативності, формування досвіду міжособистісної взаємодії. Зупинимось більш детально на характеристиці кожного із вищезазначених феноменів, на розвиток, корекцію чи формування яких була спрямована наша програма.

Формування оптимального рівня тривожності як однієї із психологічних умов розвитку індивідуальності молодшого школяра в музичній діяльності включало роботу, спрямовану на самопізнання емоційної сфери, розвиток емоційної врівноваженості (вправи «Тварини», «Налякай свій страх», гра «Що краще робити під цю музику?», техніка «Розфарбовування фігурок»). Так, вправа «Тварини» [20, с. 62], що представляє метод спрямованої фантазії, допомагає дітям у досить безпечний, м'який спосіб виявити витіснені почуття, потреби, прагнення, думки. Психолог звертається до дітей: «Уявіть, що ви - тварини» (діти вибирають за бажанням). Ви рухаєтесь, як вони, видаєте такі звуки, як вони». Дітям пропонується продемонструвати, як співають тварини, яких вони зображають, як вони звучать, показати це на музичних інструментах. Молодші школярі пояснюють кого і як вони зобразили, дають назву власній імпровізації.

Вправа «Налякай свій страх» $[20$, с. 61$]$ виконувалась у декілька етапів. Перший етап - робота зі страхами. Психолог навчає дітей ідентифікувати предмет страхів та тривожності. Наприклад, молодшим школярам пропонується зобразити власний страх на папері або вирізати його із паперу (виріж «маску» свого страху). «Як звучить твій страх? Від яких звуків тобі також страшно?». Важливо детально обговорити із дітьми названі проблеми. Другий етап. Психолог пропонує дітям фіксувати кожен випадок появи відчуття тривоги та страху в будь-який зручний для них спосіб - роблячи певні помітки-записи, замальовки, добуваючи звуки із певного музичного інструмента чи предмета. Таким чином, складається перелік того, що тривожить кожну дитину, близько 5-10 пунктів. Третіü етаn. Із кожною проблемою, страхом проводиться певна маніпуляція. Психолог забирає малюнок страху чи тривоги до «чарівної скриньки», де страх перетворюється на щось дуже добре та красиве. Перетворення супроводжується музикою. Дітям пропонується також налякати свої страхи гучними, різкими звуками (барабан, металева тарілка, залізна бочка, кришка від каструлі тощо).

«Техніка розфарбовування фігурок» [20, с. 63-64]. Дітям пропонується розфарбу- вати фігурку для того, щоб побачити, як вона почувається. Після малювання психолог проводить бесіду про почуття та емоції, зображені на малюнках. Обговорюється те, що це за почуття, коли воно виникає, що дитина відчуває, коли воно 3'являється та як можна до нього ставитися.

Підібрані нами музичні фрагменти відповідного характеру слугували ілюстраціями обговорюваних почуттів та емоцій, надаючи дітям можливість яскраво їх пережити, уявити яскравіше. Також ми пропонували дітям виявити те чи інше почуття чи емоцію звуками будь-якого музичного інструмента.

Формування адекватної самооиінки як однієї iз психологічних умов розвитку індивідуальності молодшого школяра в музичній діяльності здійснювалось засобами комплексу спеціальних вправ на самопізнання, формування адекватного уявлення про себе, про свої якості, стимулювання позитивного ставлення до себе (вправи «Мій світ у фарбах, формах і лініях», «Спонтанне малювання під музику», «Мелодизація власних якостей», ігри «Я увесь складаюсь зі звуків», «Створи портрет», «Кольорові хатинки»). Так, наприклад, у грі «Я увесь складаюсь зі звуків» [20, с. 79], метою якої $\epsilon$ самопізнання, самоідентифікація, формування образу «Я», дітям пропонується вибрати серед оточуючих музичних інструментів чи звукових предметів ті, звучання яких, на їхній погляд, найбільше їм підходять. Усі вибрані предмети та інструменти розкладаються біля кожної дитини. Під час бесіди встановлюється, чому дитина вибрала той чи інший інструмент. «Як ти себе чуєш? Як ти звучиш?». Діти складають зі звучань декількох музичних інструментів автопортрет: «Зіграй, як ти звучиш у цей момент? Як ти звучиш, коли сердишся, радієш?». Кожна дитина складає образ власного «Я» засобом комплексу звуків.

Формування позитивної мотиваиії навчання як однієї із психологічних умов становлення індивідуальності молодшого школяра забезпечувалося використанням психолого-технологічних прийомів, вправ розвитку пізнавального інтересу, зацікавленості, захопленості процесом музичної діяльності. Так, із метою стимулювання виникнення в учнів пізнавальних мотивів нами були використані такі психолого-технологічні прийоми [21, c. 17-18]:

1) прийом «захоплення кінцевим результатом діяльності», в основу якого покладена концентрація уваги особистості школяра на продукт діяльності, який би відповідав тому зразку, що собі уявляє учень, або тому, що запропонував для наслідування вчитель. Реалізація такого прийому відбувається через «проходження» учнем мобілізуючого етапу (мета якого актуалізувати, цілеспрямувати потребу в отриманні бажаного результату), прак- 
тичного етапу (безпосереднє виконання роботи) та підсумкового етапу (встановлення відповідності такого результату зразку);

2) прийом «вільний вибір завдань та способів їх виконання» дає можливість не тільки проявити творчі здібності, виконати завдання, легші за змістом, тощо, але й поступово наблизити учнів до роботи над складнішими завданнями. Вибір учнями завдання та способу його виконання зумовлений попередніми їх досягненнями або невдачами: отримання негативного результату приводить до пошуку в майбутньому легших вправ, задач, прикладів, а позитивного - важчих;

3) прийом «зіткнення мотиваційних тенденцій» спрямований на розвиток волі школярів. В основу цього прийому покладено моделювання спеціальних ситуацій, які наштовхнуть особистість учня на відстоювання своєї позиції. На шляху до отримання загальноприйнятого рішення кожна дитина аналізує власну концепцію щодо порушеного питання, якщо переконується у своїй неправоті, приймає думку інших або знаходить свій спосіб розв'язання проблемної ситуації та аргументує його всім;

4) гумористична релаксація особливо важлива під час проведення уроків у початковій школі, оскільки дає можливість учням зняти напруженість, створити сприятливі психологічні умови для подальшої роботи;

5) реалізація прийому «позитивний аналог у минулому» передбачає створення сприятливих умов для формування у свідомості учнів оптимістичної позиції через концентрацію уваги школярів на їх досягнення у минулому. Таким чином, у дітей з'являється бажання вирішувати ще складніші проблемні ситуації, розв'язувати важчі задачі тощо;

6) застосування прийому «обмін позиціями «вчитель-учень» сприяє активізації уваги дітей на особливостях викладання програмного матеріалу вчителем, прагненню здобути максимум знань 3 метою репрезентації своїх можливостей серед однокласників.

3 метою успішного управління процесом розвитку цілепокладання молодших школярів, на думку І.С. Сивової [22], систему навчально-виховних засобів необхідно орієнтувати на розвиток у молодших школярів здатності до самостійної постановки учбових цілей (встановлення учбового співробітництва вчителя та учнів у процесі постановки учбової мети, використання різних типів ситуацій свободи вибору мети, спільне планування школярами змісту уроків та перспективне планування учбового матеріалу, організація особистісно орієнтованих педагогічних ситуацій, в яких діти самостійно формулюють учбові задачі); а також розвиток умінь цілереалізації (колективне складання учнями узагальненої програми дій, пов'язаної із досягненням учбової мети, проведення колективних творчих справ, які дозволяють кожному молодшому школяреві реально ставати суб' єктом цілепокладання) [22].

Із метою розвитку здатності до самостійної постановки учбових цілей нами використовувалась технологія створення ситуацій вільного вибору декількох типів [22, с. 188]:

I тип - «ситуація свободи думок»: 1) настанова вчителя на діяльність дітей - варіанти вибору мети пропонує вчитель); 2) отримання зворотного зв'язку - висловлювання молодшими школярами власної думки; 3) рішення вчителя щодо постановки цілі - 3 урахуванням думок дітей і тих, які окреслені заздалегідь;

II тип - «ситуація жорсткого обмеження свободи вибору мети»: 1) настанова вчителя - окреслюється поле вибору мети; 2) прийняття рішення молодшими школярами - вибір одного із варіантів учбової мети; 3) оцінка вчителем успішності діяльності учня - аналіз наслідків заданої ситуації вибору; 4) наслідки ситуації вибору - оцінка наслідків власного вибору цілі учнями;

III тип - «ситуація колективного вибору»: 1) створення учителем ситуації, де кожен може i повинен висловлювати власну думку щодо постановки цілі та шляху їі досягнення; 2) узгодження думок; 3) прийняття колективного рішення; 4) колективне (групове) виконання завдань; 5) колективне проведення спільної справи; 6) колективне обговорення результату (рефлексія).

3 метою формування у молодших школярів уміння моделювати та планувати власні дії, спрямовані на досягнення поставленої учбової мети, дітям пропонувалося організовувати діяльність 3 оволодіння новими знаннями на уроках музики згідно з планом, який представлявся у візуалізованій формі [22, с. 148].

План уроку оволодіння новим знанням

1 етап - постановка мети - Що я дізнаюся? Навіщо? Для чого? Ми будемо сьогодні вивчати на уроці

Формулюю мету

2 етап - ознайомлення із новим знанням

Цим знанням я оволодіваю сам чи за допомогою учителя

3 етап - застосування нового знання у вправах

Я вчуся застосовувати нове знання

4 етап - контрольний

Я дізнаюся про себе, чи засвоїв я нове знання

Із метою усвідомлення значущості наявності мети діяльності із молодшими школярами проведена дискусія «Чи потрібна мені мета?».

Також нами використовувались такі прийоми, спрямовані на формування цілепокладання, як:

1. Формулювання мети за допомогою ключових дієслів. Дітям називається тема уроку та пропонується сформулювати мету за допомогою ключових дієслів (вивчити, знати, вміти, узагальнити, 
довести, порівняти, проаналізувати, розібратися, систематизувати, зробити висновок тощо).

2. Робота над терміном. Учням пропонується у візуальний спосіб назва теми уроку. Необхідно пояснити значення цього слова.

3. Створення проблемних ситуацій. На етапі актуалізації навчального матеріалу проводиться бесіда, спрямована на узагальнення, конкретизацію, логіку роздумів. Діалог підводиться до того, про що діти ще не можуть розповісти з огляду на необізнаність, таким чином виникає проблемна ситуація, для якої необхідні додаткові дослідження або дії, та ставиться ціль.

4. Ситуація «яскравої плями». Серед великої кількості однотипових предметів, слів, літер, фігур одне виділене кольором або розміром. Завдяки вибірковості увага концентрується на виокремленому предметі. Надалі спільними зусиллями з'ясовується причина такої виокремленості, визначається тема та мета уроку.

5. Виключення. Дітям пропонується розглянути серію слайдів (зорове сприймання) або уривки творів (слухове сприймання) та завдяки встановленню спільного, відмінного, загального віднайти зайве, обгрунтувати власний вибір [22].

Розвиток самоконтролю та саморегуляміі поведінки як однієї із психологічних умов формування індивідуальності молодших школярів передбачав оволодіння прийомами саморегуляції, формування довільної уваги, іiі зосередженості та концентрованості, подолання імпульсивності. Із цією метою нами були використані такі вправи, як «Метод спрямованої візуалізації», «Звук, що біжить», «Техніки вигадування історій за допомогою шарфа», «Чарівні дзвіночки». Так, однією із вправ, що використовувалась нами для розвитку самоконтролю та саморегуляції поведінки у молодших школярів на уроках музики, був «Метод спрямованої візуалізації» К. О’Коннор у модифікації О.А. Ворожцової [20]. Метою виконання вправи виступає розвиток самоконтролю (над власним тілом та почуттями), моделювання різноманітних життєвих ситуацій, розвиток нових практичних навичок. Кінцевою метою виступає оволодіння прийомами ефективної саморегуляції, однак на початкових етапах дитина виконує чітку інструкцію психолога. Дітям пропонується здійснити подорож у своїй уяві. В методі спрямованої візуалізації головним виступає навчання основ релаксації. Дітям пропонується лягти або зручно розташуватися на стільчику. Техніка прогресивної м'язової релаксації є одним 3 найефективніших способів підготовки дитини до проведення сеансу спрямованої візуалізації: дитину просять сконцентрувати увагу почергово на різних групах м'язів для того, щоб досягнути їх найбільшого розслаблення, наприкінці досягається розслаблення усіх м'язів.
Однак молодші школярі мають певні утруднення під час проведення техніки прогресивної м'язової релаксації через необхідність зберігати нерухомий стан. Тому, як зауважує О.А. Ворожцова [20], у такому разі більш доречною є техніка почергового напруження та розслаблення основних груп м'язів. Дітям дається інструкція зігнути пальці на ногах, а потім їх розслабити, зігнути ноги в колінах та розслабити м'язи стегон, напружити живіт та розслабити його і т. ін. Кожна група м'язів повільно напружується та розслабляється по кілька разів. I хоча саме глибока м'язова релаксація сприяє успішному проведенню спрямованої візуалізації, на початкових етапах роботи ми просили дітей просто виконувати інструкції, пов'язані з фокусуванням уваги на різних групах м'язів. Варто зазначити, що вчити дітей досягати релаксації слід 3 відкритими очима. Це допоможе їм у майбутньому активізувати свою уяву в умовах, які не зовсім сприяють зануренню в повну релаксацію. Для досягнення принаймні мінімальної релаксації вводяться елементи спрямованої візуалізації.

Музичний супровід під час виконання вправи слугує загальним фоном, що сприяє кращому розслабленню дітей. Музика 3 частотою ритму 60 ударів за хвилину допомагає дитині відчути розслаблення м'язів, зосередитися на створюваних нею в уяві образах, синхронізувати дихання, оскільки музичний ритм впливає на довжину хвиль, які генеруються мозком людини, змінює геодинаміку, обмін речовин, гуморальні реакції [20, с. 44]. Досягнувши розслаблення, діти вибудовують за допомогою психолога приємні для них образи, оживлюють приємні спогади, покликані допомогти впоратися у ситуаціях утруднення.

На цьому етапі музика продовжує свій розслаблюючий вплив, одночасно ілюструючи дитячі образи. У пам'яті дітей залишається асоціативний зв'язок між створеними ними образами та музикою у майбутньому, коли в критичній ситуації дитина вдається до допомагаючих візуальних образів із метою саморегуляції та самоконтролю, вони обов'язково будуть посилюватися аудіообразами.

У вправі «Чарівні дзвіночки» [20, с. 75-76] діти на головах мають одягнені шапочки або обідочки із дзвіночками, які дзвенять за найменшого руху. Це дозволяє в ігровій формі здійснювати контроль над власним тілом. Звуковий сигнал підсилює контролюючий ефект.

Завдання 1. Пройти так, щоб дзвоники не задзвеніли: звичним кроком, на пальчиках, на п’ятках, назад, бочком, навприсядки.

Завдання 2. Станцювати так, щоб дзвоники не задзвеніли.

Завдання 3. Рухатися, як улюблена тваринка, щоб не задзвеніти. 
Завдання 4. Естафета. Діти діляться на дві команди. В кожній команді передають м'яч так, щоб дзвоники на головах не задзвеніли. Якщо ж правила не дотримано - нараховуються штрафні бали. Перемагає та команда, яка краще впорається із завданням.

3 метою актуалізації креативності як однієї iз психологічних умов становлення індивідуальності молодшого школяра ми використовували завдання-вправи на розвиток творчих здібностей («Мелодії зими», «Малюнок-враження від почутої музики», «Вірш до почутої музики», «Якби я був композитором, моя б музика була...», «Музичний характер моїх близьких людей», «Мелодія мого улюбленого вірша» та ін.).

Так, для прикладу, метою вправи-бесіди «Мелодії зими» [23] є розвиток творчих здібностей, емоційного сприйняття музики, вміння відчувати iï настрій, порівнювати явища природи зі звучанням мелодій. Щоб дітям легше було відчувати музику, їм пропонується вільно рухатися під іï звуки, втілюючи образи в рухах. Молодші школярі навчаються порівнювати твори поетів композиторів.

Дітям пропонується виразно прочитати вірші, в яких розповідається про зимові явища та настрій людей, коли вони їх спостерігають. Молодші школярі розмірковують, якими словами можна описати певні зимові явища? I чи можна було б їхні особливості передати за допомогою музики?

Дітям за допомогою казкових героїв Джмелика, Книжечки, Пензлика та Нотки пропонується познайомитися із музичними творами композиторів.

«Зимового вечора Джмелик, Книжечка та Пензлик пробиралися через замети на гостину до Нотки. Надворі тріщав мороз, завивала хуртовина, і всі добряче змерзли. У Джмелика аж зуби цокотіли. Коли нарешті дісталися до Нотчиного будинку, він спересердя тупнув ногою, струшуючи сніг:

- От каверзна зима! Колючі сніжинки б'ють в обличчя, холодний вітер збиває з ніг...

- А мені подобається зима! - сказав Пензлик. - Особливо коли йде сніг: люблю спостерігати, як сніжинки падають одна за одною... Це просто заворожує...

- Напевно, ти відчуваєш те саме, що й композитор Клод Дебюссі. Ось один з його творів. Нотка увімкнула музику.

Молодшим школярам пропонується послухати фортепіанну п'єсу «Сніг танцює» 3 циклу К. Дебюссі «Дитячий куточок».

- Що вам нагадує початок п’єси? (Починається снігопад, з неба летять перші сніжинки, їх стає все більше, більше...).

- Що ви чуєте в музиці: плавність, наспівність чи уривчасті звуки? (То вгору, то вниз. Вони ніби і справді танцюють - це вітер здіймає і закручує їх у білому вирі).

- Як рухаються звуки-«сніжинки» - вгору чи вниз? (Уривчасті звуки, кожен - ніби колюча сніжинка).

- Коли ви будете вдома, а за вікном почнеться снігопад, увімкніть п’єсу і спробуйте послухати іiі, спостерігаючи за сніжинками.

Та чи всім композиторам подобається зима? Нотка та її друзі пропонують дітям прослухати інші зимові музичні твори: невеселий фрагмент 3 ораторії Йозефа Гайдна «Зима» й таємничо-казкову варіацію Феї зими Сергія Прокоф'єва 3 балету «Попелюшка».

Надалі учням пропонується намалювати зиму такою, якою її відтворили у музиці різні композитори.

- А чи подобається зима вам? Що у зимі добре, а що - не дуже?

- Чи існує така пора року, яку можна назвати доброю з усіх поглядів? А тільки поганою?

- Прислухайтеся до зимового оркестру, який виконує музику природи за віконечком. Які мотиви ви чуєте? Партії яких солістів розрізня$€$ єе?

- Які звуки вам подобаються, а які ні?

- Як би ви передали звуки зими за допомогою дитячих музичних інструментів?

Відпрацювання навичок міжособистісної взаємодії як однієї із психологічних умов формування індивідуальності молодшого школяра в музичній діяльності включало роботу в напрямі розвитку умінь комунікувати, розуміти один одного, взаємодіяти разом, працювати в команді, доброзичливо, чуйно, толерантно ставитися до інших. Із цією метою нами були використані техніки, вправи, ігри «Музична казка», «Музичні оповідки про іграшки», гра «Вітерець і Хмаринка», «Спільнохід», вистава «Чи другом стати може той, хто на нас не схожий?».

«Музичні оповідки про іграшки» [24] вирішують завдання слухання і обговорення музики для учнів молодших класів, навчають дітей розуміти музичну мову, зміст музичних творів, уявляти образи, які створюють композитор і виконавець. А переглядаючи твори живопису, що розповідають про дітей та їхні іграшки, молодші школярі можуть краще уявити ситуації та почуття, які описує музика. Музичні історії - привід обговорити 3 дітьми життєві ситуації, допомогти їм подивитися на власні дії збоку, звернути увагу на почуття власні та інших людей, навчитися 3 повагою ставитися до них.

Музичні твори допомагають показати дітям, як мовою звуків можна розповісти про життя людей $\mathrm{i}$ навколишній світ, висловлювати власні враження 
від музичних творів та ставлення до їхнього змісту, визначати настрій і характер музики, виражати його у пластичних рухах, відчувати смислові наголоси мелодії.

«Музика вміє передавати почуття без слів. Прислухайтеся - і відчуєте радість чи смуток, захоплення чи здивування, що їх композитор передав за допомогою нот, а музиканти-виконавці озвучили для нас, слухачів. Сьогодні ми послухаємо музичні оповідки, які не залишать байдужою жодну дитину, адже їхні головні персонажі іграшки».

Послухайте п’єсу Віктора Косенка «Не хочуть купити ведмедика».

- Весела ця музика чи сумна?

- Чи хочеться під неї усміхатися? Бігати?

- Які рухи найбільше їй відповідають? Які емоції вона викликає?

Уявіть: ви - біля вітрини іграшкового магазину. Очі розбігаються - все таке гарне... А найкращий оцей пухнастенький ведмедик. Так хочеться пригорнути його до себе й ніколи не відпускати... Варто лише попросити татуся, щоб купив... Або мамусю...

- Чи попросили б ви батьків про нову іграшку? Якщо так, то якими словами?

Але у відповідь звучить відмова... I тут до бажання мати нову іграшку додаються образа, подив - хіба дорослі не розуміють, як мені цей ведмедик подобається і як добре буде нам удвох? Можливо, варто попросити ще раз?

Послухайте музику знову. Зверніть увагу: мелодія повторюється кілька разів.

- Чи різняться повтори? Чим?

3 кожним повтором мелодія стає дедалі сумнішою, а прохання - жалібнішими. Так і чується настійливе: «Купи, купи, ну ку-п-и-и, бу-у-удь ла-а-аска-а-а...». А бажаної відповіді все немає. Ще в музиці вчуваються короткі пронизливі нотки. Як ви гадаєте, що це? Можливо, це останній «аргумент» - сльози? Крап, крап, крап... Наприкінці музика стає зовсім сумною. Мабуть, сльози котяться вже нестримним потоком...

Як ви гадаєте, чи виконають батьки таке прохання?

Чи варто за допомогою сліз умовляти рідних виконати ваші бажання?

Надалі молодшим школярам пропонувалося послухати та обговорити такі музичні п'єси про іграшки - «Купили ведмедика» Віктора Косенка (3 альбому «24 дитячі п’єси для фортепіано»); «Нова лялька», «Хвороба ляльки» Петра Чайковського (з «Дитячого альбому») - та переглянути картини художників про дітей.

Вправа «Спільнохід» [24] сприяє розвитку уміння працювати у команді, здатності до взаєморозуміння. Із цупкого картону виготовля- ються лижі із кріпленнями для двох гравців. Кожна пара отримує завдання пройти маршрут за допомогою спільнохода. Якщо це добре вдається вдвох, завдання ускладнюється - спільноходом необхідно пройти втрьох, вчотирьох, вшістьох. Вправа виконується під рухливу музику. Особливості взаємодії після виконання вправи обговорюються iз молодшими школярами: кому вдалося виконати завдання найкраще? чи можна сказати, що ви працювали як єдине ціле, як команда? чому? що вам допомагало зрозуміти одне одного? що ще може гарно вдаватися такій команді? поміркуйте, чого навчає вас така гра.

Висновки і перспективи подальших розробок у цьому напрямі. Таким чином, теоретична модель формування індивідуальності молодшого школяра в музичній діяльності, що передбачає актуалізацію психологічних умов іiі становлення, - оптимального рівня тривожності, адекватної самооцінки, позитивної мотивації навчання, ефективного цілепокладання, розвиненого самоконтролю та саморегуляції поведінки, креативності, досвіду міжособистісної взаємодії, виступає основою програми навчально-розвивальних занять 3 формування індивідуальності молодшого школяра в музичній діяльності. Навчально-розвивальні заняття «Розвиток індивідуальності молодшого школяра на уроках музики» передбачають напрями роботи, які спрямовані на формування у молодших школярів навичок самопізнання, позитивного ставлення до себе, розвитку емоційної врівноваженості, здатності до самостійної постановки цілей та умінь цілереалізації, оволодіння прийомами саморегуляції, розвиток вольових якостей, подолання імпульсивності, формування довільної уваги, розвиток пізнавального інтересу, творчих здібностей, комунікативних навичок, доброзичливості, чуйності, толерантності. Заняття програми, що являють собою комплекс вправ/процедур, представляють активні методи соціально-психологічного навчання (групова дискусія, рольова гра, вправи на самопізнання i самооцінювання, вправи для розминки), що виконуються в рамках основних видів музичної діяльності - слухання музики, співу, інтонування, гри на музичних інструментах, імпровізації, засвоєння музичних знань. Наступним етапом нашої роботи стане перевірка ефективності розробленої програми навчально-розвивальних занять 3 формування індивідуальності молодшого школяра в музичній діяльності, а також формулювання практичних рекомендацій учителям музики та шкільним психологам щодо розвитку індивідуальності у молодшому шкільному віці засобами музичної діяльності. 


\section{ЛІТЕРАТУРА}

1. Кузьменко В.У. Психолого-педагогічні основи розвитку індивідуальності дитини від 3 до 7 років : автореф. дис. ... д-ра психол. наук : 19.00.07. Київ, 2006. 41 с.

2. Баландина Л.Л. Гендерные особенности детей из многодетных и однодетных семей. Пол и Gender в интегральном исследовании индивидуальности человека / Под общ. ред. Б.А. Вяткина. Пермь : Книжный мир, 2008. С. 57-74.

3. Войтов А.С. Развитие интегральной индивидуальности младших школьников с низким уровнем учебной мотивации : автореф. дис. канд. психол. наук : 19.00.07. Пятигорск, 2014. 24 с.

4. Гребенюк О.С. Основы педагогики индивидуальности. Калининград : Изд-во КГУ, 2000. 572 с.

5. Давыдова Е.С. О влиянии личностной беспомощности на учебную активность и особенности структуры интегральной индивидуальности младших школьников. Вестник КГУ имени Н.А. Некрасова. Психология. 2007. Т. 13. С. 145-152.

6. Хрусталева Т.М. Половозрастные характеристики педагогической одаренности школьников различных возрастов. Пол и Gender в интегральном исследовании индивидуальности человека / Под общ. ред. Б.А. Вяткина. Пермь : Книжный мир, 2008. С. 231-258.

7. Шибаева С.И. Формирование индивидуальности школьника: состояние проблемы. Научные ведомости. Серия «Гуманитарные науки». 2012. № 12 (131). Выпуск 14. С. 179-183.

8. Чжуан Гуань. Методика формування творчої активності учнів початкової школи в процесі навчально-музичної діяльності : автореф. дис. ... канд. пед. наук : 13.00.02. Київ, 2017. 22 с.

9. Ненахова А.В. Развитие креативности детей 6-7 лет в процессе музыкально-игровой деятельности. Педагогика искусства. 2011. № 2. URL: http://www.art-education.ru/electronic-journal/razvitie-kreativnosti-detey-6-7-let-v-processe-muzykalno-igrovoy-deyatelnosti.

10. Травина Е. Творческое развитие учащихся на уроке музыки. Искусство в школе, 2008. № 6. С. 78-80.

11. Яненко Л.П. Формирование основ духовно-нравственной культуры младших школьников средствами музыкального искусства : автореф. дис. канд. пед. наук : 13.00.01. Елец, 2015. 25 с.

12. Сандабкина Т.Б. Формирование нравственных представлений младших школьников в процессе музыкального образования : автореф. дис. ... канд. пед. наук : 13.00.01. Улан-Удэ, 2013. 26 с.

13. Гордова О.В. Спільна музично-ігрова діяльність як засіб корекції емоційної сфери першокласників : автореф. дис. ... канд. психол. наук : 19.00.07. Київ, 2011. 25 с.

14. Алексеева Л.Л. Формирование универсальных учебных действий на уроках искусства в школе: теоретические аспекты и возможности реализации. Педагогика искусства. 2012. № 2. URL: http://www.arteducation.ru/electronic-journal/formirovanie-universalnyh-uchebnyh-deystviy-na-urokah-iskusstva-v-shkole.

15. Криницына А.В. Педагогические технологии развития самопознания младших школьников в художественно-творческой деятельности : дис. ... канд. пед. наук : 13.00.02. Москва, 2011. 263 с.

16. Мильтонян С.О. Формирование опыта межличностного взаимодействия у младших школьников в процессе музыкальной деятельности : дис. ... канд. пед. наук : 13.00.02. Кострома, 2009. 217 с.

17. Яркина Л.В. Формирование навыков мыслеречевой деятельности учащихся на уроках музыки. Педагогика и психология образования. 2014. URL: https://cyberleninka.ru/article/n/formirovanie-navykov-mysle-rechevoy-deyatelnosti-uchaschihsya-na-urokah-muzyki.

18. Королева М.Б. Музыкальная деятельность как средство развития старших дошкольников. Интернет-журнал «Науковедение». Вып. 4. 2013. URL: https://cyberleninka.ru/article/n/muzykalnaya-deyatelnost-kak-sredstvo-razvitiya-starshih-doshkolnikov.

19. Заміщак М.І. Психологічні умови становлення моральної самооцінки молодших школярів : дис. ... канд. психол. наук : 19.00.07. Дрогобич, 2014. 268 с.

20. Ворожцова О.А. Музыка и игра в детской психотерапии. Москва : Изд-во Института психотерапии. 2004. $90 \mathrm{c}$.

21. Гузенко О.А. Формування мотивації навчання молодших школярів в умовах особистісно орієнтованої освіти : автореф. дис. ... канд. пед. наук : 13.00.09. Луцьк, 2002. 21 с.

22. Сивова И.С. Развитие целеполагания младших школьников в учебной деятельности : дис. ... канд. пед. наук : 13.00.01. Волгоград, 1999. 207 с.

23. Васильєва Н. Мелодії зими. Дюсміль. № 1. 2018. С. 20-21.

24. Стеценко I. Музичні оповідки про іграшки. Джміль. № 1. 2016. С. 26-27.

\section{REFERENCES}

1. Kuzmenko, V.U. (2006). Psykholoho-pedahohichni osnovy rozvytku indyvidualnosti dytyny vid 3 do 7 rokiv [Psychological and pedagogical fundamentals of individuality development of a child aged 3-7 years]. (PhD Thesis), Kyiv. 
2. Balandina, L.L. (2008). Gendernye osobennosti detej iz mnogodetnyh i odnodetnyh semej [Gender features of children from multiple children and only-child families]. Pol $i$ Gender v integralnom issledovanii individualnosti cheloveka [Sex and Gender in the integral research of human individuality]. Perm: Knizhnyj mir, pp. 57-74.

3. Vojtov, A.S. (2014). Razvitie integralnoj individualnosti mladshih shkolnikov s nizkim urovnem uchebnoj motivacii [Development of integral individuality of junior schoolchildren having a low level of education motivation]. (PhD Thesis), Pyatigorsk.

4. Grebenyuk, O.S. (2000). Osnovy pedagogiki individualnosti [Fundamentals of individuality pedagogy]. Kaliningrad: Izd-vo KGU.

5. Davydova, E.S. (2007). O vliyanii lichnostnoj bespomoshnosti na uchebnuyu aktivnost i osobennosti struktury integralnoj individualnosti mladshih shkolnikov [On the influence of personal educational helplessness and features of the structure of integral individuality of junior schoolchildren]. Bulletin of KSU named after N.A. Nekrasov. Psychology, Vol. 13, pp. 145-152.

6. Hrustaleva, T.M. (2008). Polovozrastnye harakteristiki pedagogicheskoj odarennosti shkolnikov razlichnyh vozrastov [Age and gender characteristics of educative capacity of schoolchildren of different ages]. Pol $i$ Gender $v$ integralnom issledovanii individualnosti cheloveka [Sex and Gender in the integral research of human individuality]. Perm: Knizhnyj mir, pp. 231-258.

7. Shibaeva, S.I. (2012). Formirovanie individualnosti shkolnika: sostoyanie problemy [Formation of student's individuality: problem status]. Scientific Journal. Series Humanities, Vol. 14, No. 12 (131), pp. 179-183.

8. Zhuang, Guan (2017). Metodyka formuvannia tvorchoi aktyvnosti uchniv pochatkovoi shkoly v protsesi navchalno-muzychnoi diialnosti [Methodology of the formation of creative activity of primary school children during the educative-musical activity]. (PhD Thesis), Kyiv.

9. Nenahova, A.V. (2011). Razvitie kreativnosti detej 6-7 let v processe muzykalno-igrovoj deyatelnosti [Development of creativity of children aged 6-7 years old during the musical-play activity]. Arts Pedagogy, No. 2. Retrieved from: http://www.art-education.ru/electronic-journal/razvitie-kreativnosti-detey-6-7-let-v-processe-muzykalno-igrovoy-deyatelnosti.

10. Travina, E. (2008). Tvorcheskoe razvitie uchashihsya na uroke muzyki [Creative development of students at music lesson]. Arts in school, No. 6, pp. 78-80.

11. Yanenko, L.P. (2015). Formirovanie osnov duhovno-nravstvennoj kultury mladshih shkolnikov sredstvami muzykalnogo iskusstva [Formation of the principles of spiritual-moral culture of junior schoolchildren through the means of musical art]. (PhD Thesis), Elec.

12. Sandabkina, T.B. (2013). Formirovanie nravstvennyh predstavlenij mladshih shkolnikov v processe muzykalnogo obrazovaniya [Formation of moral ideas of junior schoolchildren in the course of musical education]. (PhD Thesis), Ulan-Ude.

13. Hordova, O.V. (2011). Spilna muzychno-ihrova diialnist yak zasib korektsii emotsiinoi sfery pershoklasnykiv [Overall musical-play activity as a means of improvement of mood of first-grade pupils]. (PhD Thesis), Kyiv.

14. Alekseeva, L.L. (2012). Formirovanie universalnyh uchebnyh dejstvij na urokah iskusstva v shkole: teoreticheskie aspekty i vozmozhnosti realizacii [Formation of the universal training actions at art school lessons: theoretical aspects and feasibility]. Pedagogy of arts, No. 2. Retrieved from: http://www.art-education.ru/electronic-journal/formirovanie-universalnyh-uchebnyh-deystviy-na-urokah-iskusstva-v-shkole.

15. Krinicyna, A.V. (2011). Pedagogicheskie tehnologii razvitiya samopoznaniya mladshih shkolnikov v hudozhestvenno-tvorcheskoj deyatelnosti [Pedagogical technologies of the development of self-awareness of junior schoolchildren in artistic-creative activity]. (PhD Thesis), Moskva.

16. Miltonyan, S.O. (2009). Formirovanie opyta mezhlichnostnogo vzaimodejstviya u mladshih shkolnikov $\mathrm{v}$ processe muzykalnoj deyatelnosti [Formation of the experience of interpersonal interaction of junior schoolchildren during musical activity]. (PhD Thesis), Kostroma.

17. Yarkina, L.V. (2014). Formirovanie navykov myslerechevoj deyatelnosti uchashihsya na urokah muzyki [Development of students' skills of cognitive-speech activity at music lessons]. Pedagogy and education psychology. Retrieved from: https://cyberleninka.ru/article/n/formirovanie-navykov-mysle-rechevoy-deyatelnosti-uchaschihsya-na-urokah-muzyki.

18. Koroleva, M.B. (2013). Muzykalnaya deyatelnost kak sredstvo razvitiya starshih doshkolnikov [Music activity as a means of the development of over-fives]. Online journal "Science Studies", Vol. 4. Retrieved from: https://cyberleninka.ru/article/n/muzykalnaya-deyatelnost-kak-sredstvo-razvitiya-starshih-doshkolnikov.

19. Zamishchak, M.I. (2014). Psykholohichni umovy stanovlennia moralnoi samootsinky molodshykh shkoliariv [Psychological conditions of the formation of moral self-esteem of junior schoolchildren]. (PhD Thesis), Drohobych. 
20. Vorozhcova, O.A. (2004). Muzyka i igra v detskoj psihoterapii [Music and playing in child mental therapy]. Moscow: Izd-vo Instituta psihoterapii [in Russian].

21. Huzenko, O.A. (2002). Formuvannia motyvatsii navchannia molodshykh shkoliariv v umovakh osobystisno oriientovanoi osvity [Formation of learning motivation of junior schoolchildren in the context of person-oriented education]. (PhD Thesis), Lutsk.

22. Sivova, I.S. (1999). Razvitie celepolaganiya mladshih shkolnikov v uchebnoj deyatelnosti [Development of goal-setting of junior schoolchildren during learning activity]. (PhD Thesis), Volgograd.

23. Vasylieva, N. (2018). Melodii zymy [Winter melodies]. Dzhmil, No. 1, pp. 20-21.

24. Stetsenko, I. (2016). Muzychni opovidky pro ihrashky [Musical stories about toys]. Dzhmil, Vol. 1, pp. 26-27. 